ISSN 1507-3866

e-ISSN 2449-9994

\title{
Jolanta Iwin-Garzyńska
}

Uniwersytet Szczeciński

e-mail: jiwin@wneiz.pl

\section{WSTĘP DO BADAŃ NAD UJEDNOLICENIEM PODSTAWY OPODATKOWANIA W UNII EUROPEJSKIEJ}

\section{INTRODUCTION TO RESEARCH TO HARMONIZE THE TAX BASE IN THE EUROPEAN UNION}

DOI: $10.15611 /$ ekt.2015.4.06

Streszczenie: Jednym z podstawowych celów prawa wspólnotowego jest zniesienie przeszkód w funkcjonowaniu rynku wewnętrznego, a w szczególności podniesienie konkurencyjności przedsiębiorstw. Celem publikacji jest ukazanie problemu ujednolicenia podstawy opodatkowania w teorii finansów przedsiębiorstwa i wskazanie na jej znaczenie dla przedsiębiorstw polskich. W opracowaniu przedstawiono istotę podatku $\mathrm{w}$ finansach przedsiębiorstwa. Dokonano analizy przychodów podatkowych oraz kosztów podatkowych ze szczególnym uwzględnieniem przychodów niestanowiących przychodów podatkowych i wydatków nieuznawanych za koszty uzyskania przychodów. Przedstawione badania mają charakter wstępu do gruntownych badań nad problemem ujednolicenia podatków dochodowych w Unii Europejskiej. Przedstawione treści odniesiono do fundamentalnych teorii finansów przedsiębiorstwa - teorii struktury kapitału.

Słowa kluczowe: podatek dochodowy, baza podatkowa, finanse przedsiębiorstw.

Summary: One of the main objectives to be accomplished by the European Union law is to eliminate barriers to the functioning of domestic market and in particular improve the competitiveness of enterprises. The paper addresses issues relating to tax in corporate finance. Canons of taxation are discussed and special emphasis is placed on principles behind formulating fiscal law provisions (including the EU law). Furthermore, the article presents the results of surveys into the importance of taxation cannons for Polish companies.

Keywords: income tax, tax base, corporate finance. 


\section{Wstęp}

Kryzys finansowy, który dotknął kraje Unii Europejskiej, uwidocznił problem systemów podatkowych obowiązujących w 27 krajach Unii Europejskiej. Problemy przedsiębiorstw wynikają ze zróżnicowanych wymogów naliczania podatku dochodowego od osób prawnych oraz braku możliwości konsolidacji wyniku finansowego dla potrzeb podatkowych.

Jednym z podstawowych celów prawa wspólnotowego jest zniesienie przeszkód w funkcjonowaniu rynku wewnętrznego, a w szczególności podniesienie konkurencyjności przedsiębiorstw. Na tym tle powstała koncepcja wspólnej jednolitej podstawy opodatkowania osób prawnych. Ma ona duże znaczenie dla kompleksowego reformowania prawa podatkowego w celu zwiększania konkurencyjności unijnych przedsiębiorstw. Koncepcja ta jest szansą na nową jakość w systemie podatkowym. Po wielu latach pracy, 16 marca 2011 r., Komisja Europejska przyjęła projekt dyrektywy w sprawie wspólnej jednolitej podstawy opodatkowania osób prawnych.

Celem publikacji jest ukazanie istoty podatku dochodowego w teorii finansów przedsiębiorstwa w nawiązaniu do podstawy opodatkowania podatkiem dochodowym i koncepcji wspólnej skonsolidowanej korporacyjnej podstawy opodatkowania. Zaprezentowane treści poparto badaniami, które mają charakter wstępu do badań nad istotą harmonizacji podatków bezpośrednich w Unii Europejskiej'.

Przeprowadzono badania ankietowe. Ankiety rozesłano do 1000 polskich przedsiębiorstw opodatkowanych podatkiem dochodowym od osób prawnych. Przedsiębiorstwa wybrano losowo spośród wszystkich przedsiębiorstw w Polsce. Ankiety rozesłano także do 500 przedsiębiorstw w państwach Unii Europejskiej, głównie niemieckich, brytyjskich, francuskich, holenderskich, włoskich i czeskich. Na ankiety odpowiedziało ogółem 112 polskich przedsiębiorstw oraz 50 podmiotów zagranicznych. W badaniu ankietowym polskich przedsiębiorstw udział wzięły głównie spółki z ograniczoną odpowiedzialnością. Jest to skutkiem tego, że spółki te są dominującą formą prowadzenia działalności gospodarczej wśród podmiotów posiadających osobowość prawną. Wśród respondentów dominowały firmy zatrudniające do 49 osób. Ankiety w firmach wypełniali przeważnie główni księgowi, co wskazuje na udział w badaniu mniejszych podmiotów, tzn. takich, w których główny księgowy odpowiada także za sprawy podatkowe. Wśród badanych podmiotów dominowały te o długim stażu działalności, tj. powyżej 5 lat, a ponad $30 \% \mathrm{z}$ nich istnieje ponad 10 lat. Analizując rodzaj prowadzonej działalności, należy podkreślić, że dominowały przedsiębiorstwa usługowe oraz handlowe. W odróżnieniu od podmiotów

${ }^{1}$ Publikacja jest po części wynikiem badań zrealizowanych w ramach projektu badawczego MNiSW nr N N113 291337 pt. Potencjat podatkowy przedsiębiorstw polskich w kontekście idei ujednolicenia podstawy opodatkowania w podatku dochodowym od osób prawnych $i$ harmonizacji prawa podatkowego w Unii Europejskiej, Kierownik projektu - prof. dr hab. Jolanta Iwin-Garzyńska, 2009-2013, a także badań statutowych Katedry Finansów Przedsiębiorstwa i Podatków Wydziału Nauk Ekonomicznych i Zarządzania Uniwersytetu Szczecińskiego. 
polskich, wśród badanych przedsiębiorstw unijnych dominowały spółki akcyjne. Były to duże przedsiębiorstwa, a największy odsetek stanowiły firmy zatrudniające powyżej 250 osób. Ankiety wypełniali głównie dyrektorzy finansowi, czyli osoby odpowiedzialne za dział podatków. Rzeczą charakterystyczną dla podmiotów zagranicznych jest to, że w firmach tych oddzielana jest księgowość od podatków, a te nadzorowane są przez dyrektorów finansowych ze względu na ich bezpośredni wpływ płatności podatkowych na płynność podmiotu i jego sytuację finansową. Analizując rodzaj działalności badanych przedsiębiorstw, należy podkreślić, że dominowały wśród nich firmy usługowe, produkcyjne i handlowe.

W jednym z wyroków Trybunału Sprawiedliwości Unii Europejskiej (dawniej ETS) orzeczono: „Chociaż władztwo podatkowe w zakresie podatków bezpośrednich znajduje się w gestii państw członkowskich, to jednak powinno być ono wykonywane zgodnie z prawem wspólnotowym".

\section{Podatki w teorii finansów przedsiębiorstwa}

Wszelkie zmiany obserwowane $\mathrm{w}$ nauce $\mathrm{i}$ teorii podatków dotyczą ich znaczenia i miejsca w praktyce finansów przedsiębiorstwa. Na tym tle rysuje się nowe znaczenie podatków w nauce finansów przedsiębiorstwa i budowany jest nowy ich paradygmat [Iwin-Garzyńska 2010]. Podatki zawsze będą powodować ryzyko w życiu przedsiębiorstw, co wynika z dużej zmienności i niepewności prawa podatkowego. Ponadto będąc kategorią wpływającą na wartość kapitału, wywołują zaburzenia w pewności bytu firmy [Iwin-Garzyńska 2010].

Podatek jest świadczeniem pieniężnym, więc każda zapłata podatku powoduje zmniejszenie zasobów, którymi przedsiębiorstwo dysponuje, czyli kapitału. Zmniejsza stan środków, które wpłynęły do firmy, poprzez wypływ środków pieniężnych na zapłatę zobowiązań podatkowych. Podatek jako ciężar, któremu w prawie nadano szczególną rangę, bezpośrednio oddziałuje na potencjał kapitałowy przedsiębiorstwa [Iwin-Garzyńska 2010].

W definiowaniu istoty podatków w finansach przedsiębiorstwa można zauważyć błąd, który polega na niedostrzeganiu podmiotowości firmy, jej organizacji [Iwin-Garzyńska 2011]. Podatek nie jest „tylko” ciężarem na rzecz państwa. Na tym tle ukazuje się waga koncepcji Common Consolidated Corporate Tax Base (CCCTB), której celem jest zniesienie przeszkód w funkcjonowaniu rynku wewnętrznego oraz ograniczenie przeszkód w działalności firm wewnątrz Wspólnoty Europejskiej. Problemy przedsiębiorstw wynikają ze zróżnicowanych wymogów naliczania podatku dochodowego od osób prawnych oraz braku możliwości konsolidacji wyniku finansowego dla potrzeb podatkowych.

Przyjęcie wspólnej skonsolidowanej podstawy opodatkowania odbędzie się w formule fakultatywnej, co oznacza, że stanie się ona 28 . systemem opodatkowania istniejącym we wspólnocie 27 systemów krajowych. Grupa firm lub pojedynczy podatnicy mieliby prawo wyboru reżimu podatkowego określonego $\mathrm{w}$ dyrektywie albo 
dalszego stosowania krajowego systemu podatku dochodowego. Projekt CCCTB jest więc ważnym krokiem na drodze do harmonizacji opodatkowania dochodu przedsiębiorstw, który zwiększając konkurencyjność zewnętrzną UE, ma jednocześnie ograniczyć szkodliwą konkurencję wewnętrzną².

W kontekście realizacji zasad opodatkowania podatkiem dochodowym, a w szczególności zasady spójności i przejrzystości systemu podatkowego, należy wskazać, że regulacja CCCTB w proponowanej dyrektywie ma charakter kompletny. Wprowadzenie dyrektywy regulującej kwestie CCCTB powinno nastąpić jedynie w momencie, gdy będą znane nie tylko wszystkie aspekty dotyczące ustalania podstawy opodatkowania i jej ewentualnego dzielenia, ale także mechanizmy funkcjonowania administracji w nowym systemie. Jest niezbędne, aby system ten był systemem kompletnym i spójnym [Iwin-Garzyńska 2012a, s. 89-90].

\section{Podstawa opodatkowania podatkiem dochodowym}

System podatku dochodowego od przedsiębiorstw oparty jest na powszechnej zasadzie, że wartość podatku, który zobowiązany jest zapłacić przedsiębiorca, zależy od podstawy opodatkowania i stawki podatku. Dochód podatkowy stanowi nadwyżka sumy przychodów nad kosztami ich uzyskania, osiągnięta w roku podatkowym, z zastrzeżeniem szczególnych zasad ustalania dochodu (przychodu) z udziału w zyskach osób prawnych oraz transakcji między podmiotami powiązanymi oraz podmiotami rezydującymi w rajach podatkowych. Jeżeli koszty uzyskania przychodów przekraczają sumę przychodów, różnica jest stratą. W określonych sytuacjach podstawę opodatkowania stanowi przychód bez uwzględniania kosztów jego uzyskania.

W unijnej koncepcji wspólnej skonsolidowanej korporacyjnej podstawy opodatkowania określono, że podstawę opodatkowania oblicza się, pomniejszając przychody o przychody zwolnione z opodatkowania, koszty podlegające odliczeniu oraz inne pozycje podlegające odliczeniu. Obok tej definicji zaproponowano normatywne ujęcie szczegółowych zasad jej ustalania. Zapisano, że dochód oblicza się według następujących zasad generalnych:

1) zasady memoriału,

2) zyski i straty rozpoznaje się tylko w chwili realizacji (zasada realizacji),

3) transakcje i zdarzenia podatkowe wycenia się indywidualnie (zasada indywidualnej wyceny),

4) obliczanie dochodu prowadzi się według jednolitych zasad, chyba że wyjątkowe okoliczności uzasadniają zmianę (zasada spójności).

W projekcie dyrektywy zdefiniowano pojęcia przychodów, zysku i straty. Pod pojęciem ,przychody” określono przychody ze sprzedaży oraz z wszelkich innych transakcji, bez podatku od wartości dodanej oraz innych podatków i należności pobranych w imieniu organów rządowych, w formie pieniężnej lub niepieniężnej, w tym dochody ze zbycia aktywów i praw, odsetki, dywidendy oraz inne wypłaty

\footnotetext{
${ }^{2} \mathrm{O}$ konkurencji podatkowej pisze m.in. L. Orędziak. Por. [Orędziak 2007].
} 
zysku, przychody z likwidacji, należności licencyjne, dotacje i subwencje, otrzymane darowizny, odszkodowania i dobrowolne płatności. Przychody obejmują również niepieniężne darowizny dokonane przez podatnika. Przychody nie obejmują kapitału pozyskanego przez podatnika ani zadłużenia spłaconego podatnikowi.

Lista zwolnień z opodatkowania podatkiem dochodowym zawarta w projekcie dyrektywy jest stosunkowo krótka. W artykule 11 Przychody zwolnione z opodatkowania zapisano:

„Zwalnia się od podatku od osób prawnych:

1) dotacje bezpośrednio związane $\mathrm{z}$ nabyciem, wytworzeniem lub ulepszeniem aktywów trwałych podlegających amortyzacji zgodnie z art. 32-42;

2) przychody ze zbycia pakietu aktywów, o którym mowa w art. 39 ust. 2, w tym wartość rynkową darowizn niepieniężnych;

3) otrzymane zyski podzielone;

4) przychody ze zbycia udziałów (akcji);

5) dochody zakładu w państwie trzecim".

Prowadząc badania dotyczące wspólnej skonsolidowanej podstawy opodatkowania i jej znaczenia dla przedsiębiorstw polskich i unijnych, zadano pytanie o znaczenie dla przedsiębiorstw przychodów niebędących przychodami podatkowymi.

Tabela 1. Znaczenie dla przedsiębiorstw polskich przychodów niebędących przychodami podatkowymi (0 - nieznaczące, 5 - mające znaczenie duże)

\begin{tabular}{|l|c|c|c|c|c|c|c|c|}
\hline \multicolumn{1}{|c|}{ Wyszczególnienie } & 0 & 1 & 2 & 3 & 4 & 5 & $\begin{array}{c}\text { Brak } \\
\text { odpowiedzi }\end{array}$ & Razem \\
\hline 1 & 2 & 3 & 4 & 5 & 6 & 7 & 8 & 9 \\
\hline $\begin{array}{l}\text { Przychody z gospodarki } \\
\text { leśnej i działalności rolniczej }\end{array}$ & $92,86 \%$ & $0,00 \%$ & $0,00 \%$ & $0,00 \%$ & $0,00 \%$ & $3,57 \%$ & $3,57 \%$ & $100,00 \%$ \\
\hline $\begin{array}{l}\text { Naliczone, lecz nieotrzymane } \\
\text { odsetki od należności, lokat } \\
\text { bankowych itd. }\end{array}$ & $66,07 \%$ & $16,07 \%$ & $7,14 \%$ & $3,57 \%$ & $1,79 \%$ & $1,79 \%$ & $3,57 \%$ & $100,00 \%$ \\
\hline $\begin{array}{l}\text { Dodatnie różnice kursowe } \\
\text { ustalone na dzień bilansowy, } \\
\text { lecz niezrealizowane }\end{array}$ & $69,64 \%$ & $8,92 \%$ & $5,36 \%$ & $1,79 \%$ & $5,36 \%$ & $5,36 \%$ & $3,57 \%$ & $100,00 \%$ \\
\hline $\begin{array}{l}\text { Dywidendy i inne przychody } \\
\text { z tytułu udziału w zyskach } \\
\text { osób prawnych }\end{array}$ & $80,36 \%$ & $1,79 \%$ & $3,57 \%$ & $8,92 \%$ & $0,00 \%$ & $1,79 \%$ & $3,57 \%$ & $100,00 \%$ \\
\hline $\begin{array}{l}\text { Zwrócone podatki, opłaty } \\
\text { i wydatki niezaliczone } \\
\text { do KUP }\end{array}$ & $69,64 \%$ & $17,85 \%$ & $5,36 \%$ & $1,79 \%$ & $1,79 \%$ & $0,00 \%$ & $3,57 \%$ & $100,00 \%$ \\
\hline $\begin{array}{l}\text { Otrzymane odsetki } \\
\text { od nadpłaconego podatku }\end{array}$ & $82,15 \%$ & $8,92 \%$ & $5,36 \%$ & $0,00 \%$ & $0,00 \%$ & $0,00 \%$ & $3,57 \%$ & $100,00 \%$ \\
\hline $\begin{array}{l}\text { Dotacje, subwencje, dopłaty } \\
\text { otrzymane na pokrycie } \\
\text { kosztów albo jako zwrot } \\
\text { wydatków }\end{array}$ & $87,50 \%$ & $7,14 \%$ & $1,79 \%$ & $0,00 \%$ & $0,00 \%$ & $0,00 \%$ & $3,57 \%$ & $100,00 \%$ \\
\hline
\end{tabular}




\begin{tabular}{|l|c|c|c|c|c|c|c|c|}
\hline \multicolumn{1}{|c|}{1} & 2 & 3 & 4 & 5 & 6 & 7 & 8 & 9 \\
\hline $\begin{array}{l}\text { Dochody uzyskane } \\
\text { od rządów państw obcych } \\
\text { pochodzące ze środków } \\
\text { bezzwrotnej pomocy }\end{array}$ & $92,85 \%$ & $1,79 \%$ & $0,00 \%$ & $0,00 \%$ & $1,79 \%$ & $0,00 \%$ & $3,57 \%$ & $100,00 \%$ \\
\hline $\begin{array}{l}\text { Dochody uzyskane } \\
\text { z działalności gospodarczej } \\
\text { prowadzonej na terenie SSE }\end{array}$ & $94,64 \%$ & $1,79 \%$ & $0,00 \%$ & $0,00 \%$ & $0,00 \%$ & $0,00 \%$ & $3,57 \%$ & $100,00 \%$ \\
\hline $\begin{array}{l}\text { Przychody z nieruchomości } \\
\text { udostępnionej nieodpłatnie }\end{array}$ & $94,64 \%$ & $1,79 \%$ & $0,00 \%$ & $0,00 \%$ & $0,00 \%$ & $0,00 \%$ & $3,57 \%$ & $100,00 \%$ \\
\hline $\begin{array}{l}\text { Przychody ustalone w drodze } \\
\text { decyzji naczelnika US }\end{array}$ & $94,64 \%$ & $1,79 \%$ & $0,00 \%$ & $0,00 \%$ & $0,00 \%$ & $0,00 \%$ & $3,57 \%$ & $100,00 \%$ \\
\hline
\end{tabular}

Źródło: obliczenia własne na podstawie badań ankietowych.

Z analizy danych zawartych w tab. 1 wynika duża nieistotność wartości przychodów niestanowiących przychodów podatkowych. Może to wynikać z faktu, że wiele tych zwolnień ma charakter szczególny i dotyczą one specyficznych przedsiębiorstw, np. w zakresie produkcji rolnej i leśnej, działalności na terenach SSE. W ogólnej grupie badanych przedsiębiorstw tych podmiotów było stosunkowo mało.

Zgodnie z zapisami w projekcie dyrektywy CCCTB za ,koszty uzyskania przychodu uznaje się wszelkie koszty poniesione przez podatnika w celach gospodarczych, związane z osiągnięciem, zachowaniem lub zabezpieczeniem przychodu, w tym koszty badań naukowych i prac rozwojowych oraz koszty podwyższenia kapitału lub zadłużenia w celach gospodarczych"3. Wynika stąd, że podlegające odliczeniu koszty związane z prowadzeniem działalności gospodarczej powinny standardowo obejmować wszystkie koszty związane ze sprzedażą oraz koszty związane z osiągnięciem, zachowaniem i zabezpieczeniem dochodu. Możliwością odliczenia objęto także koszty działalności badawczo-rozwojowej oraz koszty poniesione w celu pozyskania kapitału własnego lub obcego na potrzeby prowadzonej działalności gospodarczej.

W analizie kosztu uzyskania przychodu w koncepcji CCCTB niezwykle ważna jest kategoria związku przyczynowo-skutkowego między przychodem podatkowym i kosztem jego pozyskania. W projekcie dyrektywy zapisano, że kosztami uzyskania przychodu są ,koszty poniesione przez podatnika w celach gospodarczych, związane z osiągnięciem, zachowaniem lub zabezpieczeniem przychodu”. Warunek ten, określany jako test celu gospodarczego, jest wieloznaczny [Wspólna korporacyjna podstawa... 2011] i nieprecyzyjny. Jak wskazano wcześniej, zapis w polskiej ustawie nakazuje indywidualne podejście do każdego poniesionego przez przedsiębiorstwo kosztu, a szczególnie gdy dotyczy tzw. kosztów pośrednich związanych z zachowaniem źródła przychodu. Jednak nawet dokładna analiza nie niweluje ryzyka

${ }^{3}$ Artykuł 12 projektu dyrektywy Koszty podlegajace odliczeniu. 
podatkowego wynikającego z tego, że ocena dokonana przez organ podatkowy może być różna od subiektywnej oceny podatnika ${ }^{4}$. Z faktu, że zapis jest nieprecyzyjny, może wynikać, że ocena kosztu poniesionego przez przedsiębiorstwo będzie w efekcie także dokonywana przez sąd, gdyż ustalenie „celowości gospodarczej” poniesionego wydatku może być trudne i niejednoznaczne. Jednak należy podkreślić, iż w projekcie dyrektywy zawarto zapis, że za „,koszty uzyskania przychodu uznaje się wszelkie koszty poniesione przez podatnika w celach gospodarczych”.

W artykule 14 projektu wymieniono koszty niepodlegające odliczeniu. Zaliczono do nich m.in.:

1),zyski podzielone oraz spłaty kapitału własnego lub obcego;

2) $50 \%$ kosztów reprezentacji;

3) przeniesienie zysków zatrzymanych na pozostałe kapitały stanowiące część kapitału własnego;

4) podatek od osób prawnych;

5) łapówki;

6) grzywny i kary płatne na rzecz organu publicznego z tytułu naruszenia jakichkolwiek przepisów;

7) koszty poniesione przez przedsiębiorstwo w celu osiągnięcia dochodu zwolnionego z opodatkowania na podstawie art. 11; wysokość takich kosztów ustala się ryczałtowo na poziomie 5\% takiego dochodu, chyba że podatnik jest w stanie wykazać, że poniósł niższe koszty”.

Tabela 2. Znaczenie dla przedsiębiorstw polskich kosztów niestanowiących kosztów uzyskania przychodu w podatku dochodowym ( 0 - nieznaczące, 5 - mające znaczenie duże)

\begin{tabular}{|l|c|c|c|c|c|c|c|c|}
\hline \multicolumn{1}{|c|}{ Wyszczególnienie } & 0 & 1 & 2 & 3 & 4 & 5 & $\begin{array}{c}\text { Brak } \\
\text { odpowiedzi }\end{array}$ & Razem \\
\hline 1 & 2 & 3 & 4 & 5 & 6 & 7 & 8 & 9 \\
\hline $\begin{array}{l}\text { Wydatki na nabycie } \\
\text { gruntów lub prawa } \\
\text { wieczystego użytkowania } \\
\text { gruntów }\end{array}$ & $66,07 \%$ & $10,71 \%$ & $8,93 \%$ & $1,79 \%$ & $0,00 \%$ & $8,93 \%$ & $3,57 \%$ & $100,00 \%$ \\
\hline $\begin{array}{l}\text { Koszty z tytułu zużycia } \\
\text { samochodu osobowego } \\
\text { w czę́́ci ustalonej } \\
\text { od wartości samochodu } \\
\text { przewyższającej } \\
\text { równowartość } \\
\text { 20 000 euro }\end{array}$ & $60,72 \%$ & $12,50 \%$ & $8,93 \%$ & $7,14 \%$ & $3,57 \%$ & $3,57 \%$ & $3,57 \%$ & $100,00 \%$ \\
\hline
\end{tabular}

${ }^{4}$ W jednym z wyroków Naczelny Sąd Administracyjny stwierdził: „Aby zaliczyć wydatek do kosztów uzyskania przychodu nie wystarczy nadzieja, że taki przychód zostanie kiedyś osiągnięty. Każdy działający profesjonalnie przedsiębiorca musi bowiem analizować podejmowane operacje, a nie jedynie mieć nadzieję, że okażą się one korzystne" [Wyrok NSA z 2 grudnia 2004 r. ...]. 


\begin{tabular}{|c|c|c|c|c|c|c|c|c|}
\hline 1 & 2 & 3 & 4 & 5 & 6 & 7 & 8 & 9 \\
\hline $\begin{array}{l}\text { Wydatki na spłatę } \\
\text { pożyczek (kredytów) } \\
\text { z wyjątkiem } \\
\text { skapitalizowanych } \\
\text { odsetek od tych pożyczek } \\
\text { (kredytów) }\end{array}$ & $46,43 \%$ & $21,42 \%$ & $8,93 \%$ & $8,93 \%$ & $1,79 \%$ & $7,14 \%$ & $5,36 \%$ & $100,00 \%$ \\
\hline $\begin{array}{l}\text { Naliczone, lecz } \\
\text { niezapłacone albo } \\
\text { umorzone odsetki } \\
\text { od zobowiązań, w tym } \\
\text { również od pożyczek }\end{array}$ & $62,50 \%$ & $16,06 \%$ & $1,79 \%$ & $3,57 \%$ & $8,93 \%$ & $1,79 \%$ & $5,36 \%$ & $100,00 \%$ \\
\hline $\begin{array}{l}\text { Odsetki, prowizje } \\
\text { i różnice kursowe } \\
\text { od pożyczek (kredytów) } \\
\text { zwiększające koszty } \\
\text { inwestycji w okresie ich } \\
\text { realizacji }\end{array}$ & $73,22 \%$ & $7,14 \%$ & $3,57 \%$ & $1,79 \%$ & $3,57 \%$ & $7,14 \%$ & $3,57 \%$ & $100,00 \%$ \\
\hline $\begin{array}{l}\text { Koszty egzekucyjne } \\
\text { związane } \\
\text { z niewykonaniem } \\
\text { zobowiązań }\end{array}$ & $75,00 \%$ & $14,29 \%$ & $3,57 \%$ & $0,00 \%$ & $3,57 \%$ & $0,00 \%$ & $3,57 \%$ & $100,00 \%$ \\
\hline Grzywny i kary pieniężne & $76,78 \%$ & $10,71 \%$ & $5,36 \%$ & $1,79 \%$ & $1,79 \%$ & $0,00 \%$ & $3,57 \%$ & $100,00 \%$ \\
\hline $\begin{array}{l}\text { Wierzytelności odpisane } \\
\text { jako przedawnione }\end{array}$ & $58,93 \%$ & $19,64 \%$ & $3,57 \%$ & $0,00 \%$ & $3,57 \%$ & $1,79 \%$ & $12,50 \%$ & $100,00 \%$ \\
\hline $\begin{array}{l}\text { Odsetki za zwłokę z tytułu } \\
\text { nieterminowych wpłat } \\
\text { budżetowych i innych }\end{array}$ & $55,36 \%$ & $32,14 \%$ & $5,36 \%$ & $3,57 \%$ & $0,00 \%$ & $0,00 \%$ & $3,57 \%$ & $100,00 \%$ \\
\hline $\begin{array}{l}\text { Rezerwy utworzone } \\
\text { zgodnie z zapisami } \\
\text { ustawy o rachunkowości }\end{array}$ & $62,50 \%$ & $7,14 \%$ & $10,71 \%$ & $3,57 \%$ & $5,36 \%$ & $1,79 \%$ & $8,93 \%$ & $100,00 \%$ \\
\hline Koszty reprezentacji & $55,36 \%$ & $32,14 \%$ & $5,36 \%$ & $3,57 \%$ & $0,00 \%$ & $0,00 \%$ & $3,57 \%$ & $100,00 \%$ \\
\hline $\begin{array}{l}\text { Odpisy amortyzacyjne } \\
\text { naliczane do celów } \\
\text { podatkowych szybciej niż } \\
\text { dla celów rachunkowych }\end{array}$ & $62,50 \%$ & $7,14 \%$ & $10,71 \%$ & $3,57 \%$ & $5,36 \%$ & $1,79 \%$ & $8,93 \%$ & $100,00 \%$ \\
\hline $\begin{array}{l}\text { Odsetki od pożyczek } \\
\text { udzielonych przez } \\
\text { udziałowców }\end{array}$ & $44,64 \%$ & $25,00 \%$ & $16,07 \%$ & $1,79 \%$ & $3,57 \%$ & $3,57 \%$ & $5,36 \%$ & $100,00 \%$ \\
\hline $\begin{array}{l}\text { Aktualizacja wyceny } \\
\text { składników majątkowych } \\
\text { w księgach rachunkowych }\end{array}$ & $71,42 \%$ & $1,79 \%$ & $12,50 \%$ & $5,36 \%$ & $3,57 \%$ & $1,79 \%$ & $3,57 \%$ & $100,00 \%$ \\
\hline
\end{tabular}

Źródło: obliczenia własne na podstawie badań ankietowych.

Dla przedsiębiorstw polskich koszty nieuznawane za koszty uzyskania przychodu w podatku dochodowym nie mają dużego znaczenia. Najmniejsze znaczenie mają grzywny i kary pieniężne, koszty egzekucyjne oraz koszty odsetek, prowizji i różnic 
kursowych od pożyczek. Natomiast koszty odsetek od pożyczek udzielonych przez udziałowców już mają większe znaczenie dla podatników.

\section{Finanse przedsiębiorstwa, struktura kapitału a koncepcja CCCTB}

Problematyka podatku dochodowego w finansach przedsiębiorstwa jest bardzo obszerna. W tym miejscu poruszone zostaną zasadnicze zagadnienia dotyczące rozwiązań podatkowych z zakresu koncepcji CCCTB w kontekście teorii finansów przedsiębiorstwa.

W badaniu struktury kapitału i jej wpływu na wartość przedsiębiorstwa przełom stanowiło zaangażowanie się w tę problematykę Franco Modiglianiego oraz Mertona H. Millera, którzy w 1958 r. opublikowali artykuł zatytułowany Koszt kapitału, finanse przedsiębiorstwa i teoria inwestycji [Modigliani, Miller 1958]. Artykuł ten zapoczątkował cykl publikacji dotyczących tego zagadnienia, otworzył wieloletnią, trwającą do dziś, dyskusję na temat konsekwencji dla finansów przedsiębiorstw i wartości firmy wynikających z przyjętej struktury kapitału. Z teorii MM (teorii Modiglianiego i Millera) wynika, że w świecie bez podatków zarówno wartość firmy, jak i jej WACC nie zależą od struktury kapitału.

W 1963 r. Modigliani i Miller opublikowali artykuł będący korektą teorii nieistotności struktury kapitału [Modigliani, Miller 1963]. Poruszyli w nim problem pozostający $\mathrm{w}$ centrum zainteresowania finansów przedsiębiorstwa. Problemem tym jest określenie roli podatków w kształtowaniu polityki finansowej przedsiębiorstwa [Ashton 1991]. Autorzy przedstawili skorygowany wpływ struktury kapitału na wartość firmy przy występowaniu podatku dochodowego od przedsiębiorstwa, twierdząc, że w tych warunkach istnieje optymalny poziom finansowania przedsiębiorstwa kapitałem obcym, czyli optymalna struktura kapitału. Kluczem do analizy było uwzględnienie zróżnicowania opodatkowania (asymetria podatkowa) dochodów akcjonariuszy i wierzycieli na szczeblu przedsiębiorstwa [Martin, Cox, McMinn 1988]. Koszty odsetek od kapitału obcego pomniejszają podstawę wymiaru podatku dochodowego, a dywidendy i zyski zatrzymane nie pomniejszają jej [Schall, Haley 1991]. Wobec tego przy wykorzystywaniu kapitałów obcych pojawia się odsetkowa tarcza podatkowa. Kiedy odsetki są odejmowane od podstawy wymiaru podatku dochodowego firmy, wartość jednostki gospodarczej korzystającej z finansowania długiem przewyższy wartość firmy, która nie wykorzystuje kapitału obcego o skapitalizowaną wartość tarczy podatkowej.

Wprowadzając system podatkowy umożliwiający pomniejszanie podstawy wymiaru podatku o koszty finansowe w postaci odsetek od długu, Modigliani i Miller udowodnili, że tańszy kapitał obcy (na skutek działania odsetkowej tarczy podatkowej) wpływa na wzrost wartości firmy ogółem. Jednocześnie po raz pierwszy uwypuklili wagę podatków w polityce finansowej przedsiębiorstwa, której celem jest wzrost wartości firmy. 
Teoria Modiglianiego i Millera z 1963 r. miała ogromne znaczenie dla uwypuklenia roli podatków w finansach przedsiębiorstw. Udowodnili, że można kształtować strukturę kapitału i wartość firmy przez politykę podatkową. Warto podkreślić, że ten aspekt podatków jest także dziś mało dostrzegany przez zarządzających podatkami w przedsiębiorstwach. Aktualnie nader często podatki traktowane są jako ciężar fiskalny, a nie jako przepływ, którym można sterować, wpływając efektywnie na wartość przedsiębiorstwa. W odniesieniu do koncepcji CCCTB teoria ta niewątpliwie uzasadnia wprowadzenie jednego systemu opodatkowania przedsiębiorstw w Unii Europejskiej, tak aby wszystkie podmioty miały równe szanse kształtowania swej wartości przez wykorzystanie polityki podatkowej.

Występowanie pozaodsetkowych tarcz podatkowych było powodem modyfikacji badań prowadzonych przez Millera. Zostały one uzupełnione koncepcjami opracowanymi przez Harry'ego DeAngelo i Ronalda W. Masulisa. Autorzy ci, podkreślając rolę inwestycyjnej tarczy podatkowej w determinowaniu optymalnej struktury podatkowej, wykazali, że firma mająca dużą wartość nieodsetkowych tarcz podatkowych może mieć taką samą wartość jak firma korzystająca $\mathrm{z}$ wysokiego zadłużenia i tym samym wysokiej tarczy odsetkowej. Wyższa wartość amortyzacyjnej tarczy podatkowej powoduje niższą tarczę odsetkową. Odnosi się do tego stwierdzenie wynikające z badań Masulisa, że występowanie różnorodnych tarcz podatkowych może tworzyć optymalną strukturę kapitału dla każdego przedsiębiorstwa i gospodarki jako całości ${ }^{5}$. Optymalna struktura kapitału zostanie osiągnięta przy poziomie zadłużenia, przy którym wartość ogółem tarcz podatkowych, odsetkowej i amortyzacyjnej, jest kwotą maksymalną do odliczenia w danych warunkach opodatkowania.

$\mathrm{Z}$ analizy przedstawionych teorii wynika duże znaczenie długu i podatkowej tarczy odsetkowej w kształtowaniu optymalnej struktury kapitału przedsiębiorstwa. Wynika z tego waga rozwiązań systemowych dotyczących skutków podatkowych finansowania firmy długiem.

Rozwiązania, które mogą wpływać na wielkość i strukturę kapitałów firmy, zawarto w projekcie dyrektywy CCCTB. Przyjęcie w praktyce prostego założenia, że odsetki zmniejszają koszt długu na skutek zaliczenia ich do kosztów uzyskania przychodu w podatku dochodowym, byłoby dużym uproszczeniem.

Zgodnie z zapisami ustawy o podatku dochodowym od osób prawnych nie uważa się za koszty uzyskania przychodów wydatków na spłatę pożyczek (kredytów), z wyjątkiem skapitalizowanych odsetek od tych pożyczek (kredytów). Oznacza to, że odsetki mogą być uznane za koszty uzyskania przychodów z chwilą ich kapitalizacji. W znaczeniu prawnym w przypadku stosunku zobowiązaniowego zapłata jest

\footnotetext{
${ }^{5} \mathrm{~W}$ weryfikacji empirycznej teorii DeAngelo i Masulisa w polskich przedsiębiorstwach nie stwierdzono jej prawdziwości. Przedsiębiorstwa polskie mające wysoką tarczę amortyzacyjną, będącą substytutem tarczy odsetkowej, nie korzystają w mniejszym stopniu z długu. Przedsiębiorstwa, które mają dług w swej strukturze kapitału, w dużo większym stopniu korzystają z efektu amortyzacyjnej tarczy podatkowej [Iwin-Garzyńska 2004, s. 25-34].
} 
jedną z form spełnienia świadczenia przez dłużnika, która prowadzi do umorzenia zobowiązania [Iwin-Garzyńska 2012b].

Zasady ogólne przepisów ustawy nie przewidują innej możliwości rozliczenia wydatków z tytułu odsetek niż bezpośrednie zaliczenie do kosztów uzyskania przychodów, poza wyraźnie wskazanymi wyjątkami (np. odsetki naliczone do dnia przekazania środka trwałego do używania podlegają kapitalizacji do jego wartości początkowej i są efektywnie rozpoznawane jako koszt uzyskania przychodu przez odpisy amortyzacyjne) ${ }^{6}$. Także zgodnie z zapisami ustawy nie uważa się za koszty uzyskania przychodów „naliczonych, lecz nie zapłaconych albo umorzonych odsetek od zobowiązań, w tym również od pożyczek (kredytów)" [Ustawa z dnia 15 lutego 1992 r. o podatku dochodowym..., art. 16 ust. 1 pkt 11].

Kolejnym kosztem związanym z zaciąganiem długu przez przedsiębiorstwo są prowizje i opłaty. Co do zasady, prowizja z tytułu pożyczek to wydatek niesłużący bezpośrednio celom, na jakie została zaciągnięta pożyczka, ale umożliwiający uzyskanie źródła finansowania.

Tabela 3. Znaczenie kosztów podatkowych związanych z wykorzystaniem długu dla przedsiębiorstw polskich $(0$ - nieistotne, 5 - istotne $)$

\begin{tabular}{|l|c|c|c|c|c|c|c|c|}
\hline \multicolumn{1}{|c|}{ Wyszczególnienie } & 0 & 1 & 2 & 3 & 4 & 5 & $\begin{array}{c}\text { Brak } \\
\text { odpowiedzi }\end{array}$ & Razem \\
\hline $\begin{array}{l}\text { Wydatki na spłatę pożyczek } \\
\text { (kredytów) z wyjątkiem } \\
\text { skapitalizowanych odsetek } \\
\text { od tych pożyczek (kredytów) }\end{array}$ & $46,4 \%$ & $21,4 \%$ & $8,9 \%$ & $8,9 \%$ & $1,8 \%$ & $7,2 \%$ & $5,4 \%$ & $100 \%$ \\
\hline $\begin{array}{l}\text { Naliczone, lecz niezapłacone albo } \\
\text { umorzone odsetki od zobowiązań, } \\
\text { w tym również od pożyczek } \\
\text { (kredytów) }\end{array}$ & $62,5 \%$ & $16,1 \%$ & $1,8 \%$ & $3,5 \%$ & $8,9 \%$ & $1,8 \%$ & $5,4 \%$ & $100 \%$ \\
\hline $\begin{array}{l}\text { Odsetki, prowizje i różnice kursowe } \\
\text { od pożyczek (kredytów) zwiększające } \\
\text { koszty inwestycji w okresie ich } \\
\text { realizacji }\end{array}$ & $73,2 \%$ & $7,1 \%$ & $3,6 \%$ & $1,8 \%$ & $3,6 \%$ & $7,1 \%$ & $3,6 \%$ & $100 \%$ \\
\hline $\begin{array}{l}\text { Odsetki od pożyczek udzielonych } \\
\text { przez udziałowców }\end{array}$ & $80,4 \%$ & $1,8 \%$ & $5,3 \%$ & $1,8 \%$ & $1,8 \%$ & $5,3 \%$ & $3,6 \%$ & $100 \%$ \\
\hline
\end{tabular}

Źródło: opracowano na podstawie badań ankietowych.

Dla przedsiębiorstw polskich rozwiązania podatkowe dotyczące zaliczania do kosztów uzyskania przychodu w podatku dochodowym kosztów będących następstwem pozyskania długu nie są istotne. Ponad $45 \%$ ankietowanych wskazało, że nieważny jest fakt, iż wydatki na spłatę pożyczek (kredytów) nie stanowią kosztów uzyskania przychodu, a jedynie dla ponad 7\% jest to znaczne ograniczenie. Nie sta-

\footnotetext{
${ }^{6}$ Podobne stanowisko w zakresie określenia momentu potrącalności odsetek prezentuje także Ministerstwo Finansów, np. w [Interpretacja indywidualna Dyrektora Izby Skarbowej...].
} 
nowi także problemu niemożność pomniejszenia podstawy opodatkowania o naliczone, lecz niezapłacone lub skapitalizowane odsetki. W jeszcze większym stopniu nieistotne są odsetki i prowizje zapłacone w trakcie realizacji inwestycji rzeczowych i stanowiące ich wartość początkową oraz odsetki od pożyczek udzielanych przez udziałowców. Dowodzi to faktu, że przedsiębiorcy polscy nie dostrzegają wagi kosztów podatkowych długu jako zmniejszających efektywny koszt pozyskania kapitału obcego w postaci kredytów, pożyczek. Nie stanowi także problemu fakt, że odsetki od długu można zaliczyć do kosztów uzyskania przychodu tylko wtedy, gdy zostały zapłacone lub skapitalizowane. Na tym tle można wskazać, że propozycje Komisji Europejskiej mogłyby być w tym zakresie akceptowane przez przedsiębiorstwa polskie [Iwin-Garzyńska 2012c].

W koncepcji nie odniesiono się precyzyjnie do kosztów odsetek jako kosztu uzyskania przychodu. Z ogólnej definicji (por. [Council Directive on a Common Consolidated... art. 12, s. 23]) kosztów wynika, że wszelkie koszty poniesione przez przedsiębiorstwo w związku z pozyskaniem i obsługą długu będą stanowić koszty podatkowe. Nie będzie stanowić kosztu uzyskania przychodu spłata zaciągniętych długów (np. kapitału kredytowego). Jest to rozwiązanie tożsame z tym obowiązującym w ustawie o podatku dochodowym od osób prawnych.

$\mathrm{W}$ analizie kosztów podatkowych długu według koncepcji CCCTB szczególnie ważna jest przyjęta $\mathrm{w}$ rozwiązaniach zasada memoriału. Według zapisów polskiej ustawy odsetki są zaliczane do kosztów uzyskania przychodu według zasady kasowej. Zasada memoriału stosowana jest także w MSR/MSSF. Można stąd wnioskować, że koszty odsetkowe pomniejszałyby podstawę opodatkowania w momencie ich naliczenia, a nie faktycznej zapłaty. Jest to rozwiązanie korzystne dla przedsiębiorstw, przybliżające zasady podatkowe do rozwiązań rachunkowych.

\section{Uwagi końcowe}

System podatku dochodowego w Unii Europejskiej wymaga ujednolicenia, aby stać się konkurencyjny wobec Chin, Rosji, Stanów Zjednoczonych itd. Obecnie państwa Unii nie stanowią jednego organizmu podatku dochodowego, ale 27 różnych podmiotów, które muszą konkurować ze sobą wewnątrz Unii, a także poza nią. Celem winno być ujednolicenie systemu podatku dochodowego od przedsiębiorstw, aby wszystkie firmy w ramach UE miały porównywalne warunki pracy w aspekcie podatku dochodowego, a na zewnątrz Unii stanowiły jeden organizm. Zgodnie z ideą koncepcji CCCTB ujednoliceniu będzie podlegać baza podatku, czyli zasady kształtowania przychodów i kosztów podatkowych.

Z przeprowadzonych badań wynika, że dla polskich i unijnych przedsiębiorstw proponowana koncepcja może być korzystna. Przedsiębiorcy dostrzegają korzyści wynikające z proponowanych rozwiązań. Wśród firm panuje jednak powszechna niechęć do mówienia o podatkach w sposób rzeczowy. Niechęć ta może być skutkiem braku zaufania do otwierania dokumentacji podatkowej przed osobami z zewnątrz, nawet 
w celu prowadzenia badań naukowych. Jest to ogromna szkoda dla nauki finansów, finansów przedsiębiorstwa, prawa, a także jakości stanowionego prawa. Przeprowadzone badania ankietowe pozwalają rozpoznać ogólny pogląd przedsiębiorstw polskich na kategorie przychodów i kosztów w podatku dochodowym.

\section{Literatura}

A Common Consolidated EU Corporate Tax Base, 2004, Commission Non-Paper to informal Ecofin Council.

Ashton D.J., 1991, Corporate financial policy: American analytics and U.K. taxation, Journal of Business Finance and Accounting.

Council Directive on a Common Consolidated Corporate Tax Base (CCCTB), European Commission, Brussels, COM(2011) 121/4, 2011/0058 (CNS) \{SEC(2011) 315\}\{SEC(2011) 316$\}.$

Interpretacja indywidualna Dyrektora Izby Skarbowej w Warszawie z 8 kwietnia 2009 r., sygn. IPPB3/423-28/09-2/ER.

Iwin-Garzyńska J., 2004, Empirical verification of depreciation tax shield theory in conditions of Polish economy in transformation, Ekonomia, Wydawnictwo Uniwersytetu Warszawskiego, kwartalnik, nr 15.

Iwin-Garzyńska J., 2010, Szkice o kapitale i podatkach w istocie nauki finansów przedsiębiorstw, Difin, Warszawa.

Iwin-Garzyńska J., 2011, Kapitał i podatki w nauce finansów przedsiębiorstw, Finanse, nr 4, PAN INoF, Warszawa.

Iwin-Garzyńska J., 2012a, Opodatkowanie kosztu długu przedsiębiorstw a koncepcja Wspólnej Skonsolidowanej Korporacyjnej Podstawy Opodatkowania, [w:] Finanse w niestabilnym otoczeniu - dylematy $i$ wyzwania. Finanse przedsiębiorstw, red. T. Famulska, A. Walasiak, Wydawnictwo Uniwersytetu Ekonomicznego w Katowicach, Katowice.

Iwin-Garzyńska J., 2012b, Wspólna Skonsolidowana Korporacyjna Podstawa Opodatkowania szansa dla przedsiębiorstw polskich, Roczniki Naukowe Wyższej Szkoły Bankowej w Toruniu, red. Maria Dragun-Gertner, Wyższa Szkoła Bankowa w Toruniu, Toruń.

Iwin-Garzyńska J., 2012c, Wspólna Skonsolidowana Korporacyjna Podstawa Opodatkowania szansa rozwoju regionu, Zeszyty Naukowe Uniwersytetu Szczecińskiego, Ekonomiczne Problemy Usług, nr 63, Wydawnictwo Naukowe Uniwersytetu Szczecińskiego, Szczecin.

Martin J.D., Cox S.H., McMinn R.D., 1988, The Theory of Finance. Evidence and Applications, The Dryden Press, Chicago.

Modigliani F., Miller M.H., 1958, The cost of capital, corporation finance and the theory of investment, American Economic Review.

Modigliani F., Miller M.H., 1963, Corporate income, taxes and the cost of capital. A correction, American Economic Review.

Orędzik L., 2007, Konkurencja podatkowa i harmonizacja podatków w ramach Unii Europejskiej, Wyd. WSHiP Elipsa, Warszawa.

Schall L.D., Haley Ch.W., 1991, Introduction to Financial Management, McGraw-Hill International Editions, New York.

Ustawa z dnia 15 lutego 1992 r. o podatku dochodowym od osób prawnych, Dz.U. 1992 nr 21, poz. 86.

Wspólna korporacyjna podstawa opodatkowania w UE a opodatkowanie dochodu spótek $w$ Polsce (2011), red. H. Litwińczuk, Oficyna Prawa Polskiego, Wydawnictwo Wiedza i Praktyka, Warszawa.

Wyrok NSA z 2 grudnia 2004 r. FSK 1215/04, „Rzeczpospolita” z dnia 3.12.2004 r. 